Jakub Forst Battaglia

Kijów-Wiedeń

\title{
MIĘDZY WIEDNIEM A GALICJĄ, AUSTRIA A POLSKA. KALEJDOSKOP STOSUNKÓW KULTURALNYCH OD XVIII DO XX WIEKU
}

\section{Warunki rozwoju}

Arystokratyczni wielbiciele sztuk, pisarze, kompozytorzy, malarze i rzeźbiarze z ziem polskich, przyciągani blaskiem dworu cesarskiego, towarzyskiego i umysłowego znaczenia Wiednia, przyjeżdżali chętnie do stolicy Cesarstwa. Zaczeło się to na większą skalę z końcem XVIII wieku po rozbiorach Polski aż do wczesnych lat 20. XX wieku. Żyło się w jednym państwie, podzielając wspólnie jego losy. Polacy wiedeńscy zarazem tworzyli swoją kulturę narodową i współtworzyli bujną i różnorodna, jakby ponadnarodową kulturę starej Austrii i metropolii naddunajskiej, która również wpłynęła na ich twórczość, umożliwiając rozszerzenie światopoglądu.

Polacy służyli na odpowiedzialnych stanowiskach dworskich, ministerialnych, wojskowych i przy najwyższych posadach Monarchii. Stanowili naturalną część elit wiedeńskich, zarazem zachowując swoją polską tożsamość, co w owych czasach dało sie latwo pogodzić.

Z drugiej strony niemieckojęzyczni Austriacy jako urzędnicy i wojskowi, poprzez kontakty towarzyskie, polityczne i kulturalne zetknęli sie z Polakami i z polskim życiem umysłowym, zarówno w Galicji, w Wiedniu, a także na dalszych terenach polskich i austriackich.

Po upadku Monarchii na skutek I wojny światowej sytuacja o tyle się zmieniła, że wielu Polaków wyjechało do wskrzeszonej na nowo ojczyzny, którą woleli od małej, niemieckojęzycznej, dramatycznie doświadczonej trudnym losem Republiki Austriackiej. Nie dotyczyło to wszystkich, ale licznych osobistości. W nowej Polsce wnieśli ogrom doświadczeń z dobrze stosunkowo działającego państwa, a politycy, tacy jak Ignacy Daszynski 
lub Wincenty Witos, odegrali niemałą rolę w polityce okresu międzywojennego, byli szybko odsuwani od wpływowych stanowisk przez ludzi wywodzących sie z zaboru rosyjskiego lub pruskiego.

Jednak stosunki istniały dalej, już w skromniejszym stopniu, aby po ciemnych latach hitleryzmu i wojny a trudnych latach powojennych w których Polska i Austria znalazły sie po dwóch stronach Żelaznej Kurtyny, sztucznie podzielającej Europę móc dojść do nowego rozkwitu w warunkach wolnej, zjednoczonej Europy naszych czasów. Przedtem już, dzięki powstałemu w 1964 r. Instytutowi Austriackiemu w Warszawie a dziesięć lat później Instytutowi Polskiemu w Wiedniu, starano sie też ze strony oficjalnej rozwijać wymianę kulturalną i naukową w sposób przykładowy między Wschodem a Zachodem.

Warto przypomnieć takie osobistości jak Fritz Cocron, Hans Marte i Richard Sickinger jako dyrektorów austriackich w stolicy nadwiślańskiej, którzy odegrali niemałą rolę we wzajemnym zrozumieniu, tworząc umysłowe okno na świat w okresie komunizmu w Polsce Ludowej. Austriacki Instytut Kultury w Warszawie odegrał szczególnie ważną rolę jako okno na świat w okresie smutnego stanu wojennego po $1981 \mathrm{r}$. W ogóle wiele intelektualistów polskich w związku z powstaniem Solidarności a następnie po 13 grudnia 1981 r. przebywało w Austrii na dłuższej lub krótszej emigracji, gdzie nieugięty polski ruch wolnościowy dążący do demokratycznych rządów i poszanowania praw człowieka wzbudzał wiele sympatii zwłaszcza w wykształconych kołach społeczeństwa.

Dzisiaj rozbudową stosunków kulturalnych i szerzeniem współczesnych prądów w swobodnych warunkach zajmują się Instytut Polski w Wiedniu oraz Austriacke Forum Kultury w Warszawie. Kulturę polską kołom austriackim umiejętnie przybliżali w nowych warunkach demokratycznych germanista i tłumacz literacki Jacek Buras i poetka krakowska Ewa Lipska. Były i inne osobistości, o których jeszcze będzie mowa. Obecnie w XXI wieku możliwości są różnorodne po obydwu stronach. Dziesiątki tysiecy Polaków mieszka w Austrii, wiele Austriaków jeździ do Polski. W Wiedniu warto szczególnie przypomnieć nadzwyczaj chlubne zasługi poniesione przez Stację Naukową Polskiej Akademii Nauk, która się z czasem rozwinęła do roli katalizatora bujnej wymiany naukowej i intelektualnej w naukach humanistycznych i innych dziedzinach wiedzy. Myślę tu zwłaszcza o roli odgrywanej przez dyrektorów Stacji: Romana Taborskiego, polonisty warszawskiego i wieloletniego badacza poloników wiedeńskich oraz Bogusława Dybasia, historyka z Torunia, nadzwyczaj czynnego budowniczego pomostów między kołami intelektualnymi Polski i Austrii.

Funkcje znakomitych katalizatorów wzajemnych stosunków pełnili pierwsi ambasadarowie wolnej III Rzeczpospolitej w Wiedniu, Włady- 
sław Bartoszewski, Jan Barcz i Irena Lipowicz, spajając nowe, solidne więzi przyjaźni między Polakami a Austriakami, pogłębiając przy tym obupólne, rzetelne zrozumienie i przybliżenie w duchu współpracy europejskiej. Ich następcy mieli i mają najlepsze warunki kontynuowania tych elegancko wytoczonych dróg.

$\mathrm{Z}$ trudnych lat powojennych należy wymienić troje barwnych postaci, starających sie o odnowienie poprawnych stosunków. Byli to w latach czterdziestych znany pisarz i satyryk Stanisław Jerzy Lec, attaché kulturalny i prasowy przy ówczesnej Misji Politycznej oraz poseł Feliks Mantel, adwokat i blyskotliwy publicysta, stary PPS-owiec rodem z Przemyśla, który „wybrał wolność“ w obliczu narastającego stalinizmu jeszcze przed kongresem zjednoczeniowym PPS i PPR. O dziesięć zgoła lat później we wcześniejszym okresie gomułkowskim, za rządów ministra spraw zagranicznych Adama Rapackiego ambasadorem został Karol Kuryluk, poprzednio minister kultury z lat 1956-58. Kuryluk jako ambasador starał się o przyjazne stosunki z elitami intelektualnymi Austrii, chcąc od 1958 r. zaprezentować uprzejme oblicze Polski Ludowej po tak zwanej "odwilży” października w 1956 r. Ten niekonwencjonalny intelektualista lewicowy pochodzący ze Lwowa, ongiś redaktor naczelny "Sygnałów" i „Odrodzenia”, stał sie jednym ze "Sprawiedliwych wśród narodów” w spisie jerozolimskiego Jad Waszem za ratowanie Żydów lwowskich w czasie okupacji hitlerowskiej. Jego córka Ewa Kuryluk, wybitna artystka i pisarka, poświęciła oryginalną książkę secesji w Wiedniu.

Z wielu austriackich ambasadorów akredytowanych w Polsce, do których zadań należało utrzymywanie dobrych kontaktów z kręgami polskiej inteligencji przykładowo zasługują na wyróżnienie Stephan Verosta, Richard Wotava, Peter Pramberger i Gerhard Wagner.

\section{Salony i mecenat}

Wraz z końcem XVIII wieku Adam Kazimierz Czartoryski dowodził gwardią galicyjską $\mathrm{w}$ Wiedniu. Jedną z pamiątek po tym pobycie jest kościół zbudowany na Rennwegu należący dzisiaj do polskiej parafii. Jego syn Konstanty (1773-1860), brat paryskiego „króla de facto” Adama Jerzego, zamieszkał w 1828 r. w Wiedniu, gdzie od 1832 r. wybudował pałacyk Weinhaus, rozebrany później w 1957 r. Położony w pieknym parku, ten mały obiekt zawierał zbiory sztuki i stanowił jeden z głównych eleganckich, czołowych na polu kultury salonów Wiednia. Wirtuozi tacy jak Hector Berlioz i Franz Liszt dawali tam koncerty, znani aktorzy wystawiali sztuki francuskie i niemieckie. Synowie księcia kontynuowali długo te tradycje. 
Józef Maksymilian Ossoliński (1748-1826), to jedna z najbardziej zasłużonych osobistości swego czasu dyrektor wiedeńskiej Biblioteki Nadwornej, kolekcjoner sztuki i bibliofil, przyjaciel Beethovena, zamieszkiwał pałac nie istniejący już dzisiaj naprzeciwko wiedeńskiego Theresianum i był założycielem słynnego Ossolineum we Lwowie w 1827 r. Dzisiaj w tym budynku mieści się Biblioteka im. Wasyla Stefanyka Ukraińskiej Akademii Nauk a polskie Ossolineum przeniosło sie po 1945 r.do Wrocławia.Teraz obie, nieco sztucznie podzielone instytucje blisko współpracują.W 2009 r. z inicjatywy wrocławskiego dyrektora Adolfa Juzwenki w wiedeńskiej Bibliotece Narodowej pokazano wielką wystawę rzadkich książek i starodruków, po przeszło sześćdziesięciu latach jednocząc po raz pierwszy zbiory polskie i ukraińskie, pochodzące ze słynnej instytucji.

Wokól Ossolińskiego, którego zasługi są znane także w dziesiejszym Wiedniu, szereg zagorzałych przyjaciół świata słowiańskiego zebrało się w stolicy Cesarstwa pod patronatem Samuela Bogumiła Lindego, twórcy pierwszego historycznego słownika języka polskiego.

Szczególnie znaną i cenioną postacią starego Wiednia byl Karol hr.Lanckoroński-Brzezie (1848-1933), wielki pan - „całą gębą“, posiadający obok kolekcji Harrachów i Liechtensteinów - jedną z największych prywatnych zbiorów sztuki stolicy naddunajskiej.

Ten czolowy przedstawiciel Polaków wiedeńskich piastował wysokie godności jako Rycerz Orderu Złotego Runa, członek Izby Panów i Szambelan Cesarski, posiadał pałac za wiedeńskim Belwederem i szereg dóbr w Galicji. Ów miłośnik starożytności i renesansu potepiał jednakowoż nowoczesne prądy w sztuce, czy to wiedeńskiej Secesji czy Młodej Polski, protegując tylko klasycznych malarzy akademickich. Zajmował sie ochroną zabytków, jak odrestaurowaniem bazyliki w Akwilei (dzisiaj we Włoszech, wtedy w Austrii) i wykopaliskami archeologicznymi, w czym był podobny do swego (o 15 lat młodszego) rówieśnika, zamordowanego w 1914 r. w Sarajewie arcyksięcia Franciszka Ferdynanda.

Córka hrabiego Lanckorońskiego - Karolina (1898-2002), znany historyk sztuki, więziona w obozie hitlerowskim w Ravensbrück, zdołała też dzieki pomocy przyjaciół wyratować wspaniałe zbiory po ojcu, które częściowo spłoneły w pałacu wiedeńskim lub przepadły, rozproszone po świecie. Przechowywane w Rzymie i Londynie, po upadku komunizmu zostały podarowane wolnej Polsce.

W życiu politycznym i towarzyskim Wiednia szereg osobistości galicyjskich, premierzy jak Agenor hr.Gołuchowski starszy, Alfred hr. Potocki i Kazimierz hr. Badeni, minister spraw zagranicznych Agenor hr. Gołuchowski młodszy lub ministrowie finansów Julian Dunajewski i Leon Biliński odgrywali ważna rolę w życiu Wiednia. Przez pół wieku do każdego 
rządu zaliczano ministrów do spraw Galicji „,bez portfela“. Jeden z nich, Kazimierz Chledowski (1843-1920), piszący po części pod pseudonimem „Ignotus“, ostrym piórem satyryka rysował zgryźliwe portrety różnych polskich i niepolskich postaci życia publicznego Wiednia, a nawet zabłysnał jako autor powieści kryminalnej „Po nitce do kłębka“.

Świetny znawca historii sztuki i miłośnik renesansu oddawał sie wnikliwym studiom nad dawnymi Włochami dotyczącymi głównie Rzymu, Florencji i Ferrary. Należał do kręgu najbardziej „zwiedeńszczonych“ lub inaczej „,czarnożółtych“ Polaków z Galicji, których losy do końca były ściśle splątane z losami Austrii wielonarodowej i jej dynastii panującej. Jego "Pamiętniki" pozostają nieocenionym źródłem wiedzy o życiu towarzyskim i kulturalnym Wiednia podobnie jak barwne „Wspomnienia” szambelana dworskiego z ormiańskiego rodu Mariana Rosco-Bogdanowicza (1862-1955).

\section{Krąg literatów}

Najbardziej chyba znanym z posród pisarzy polskich, którzy chętnie i długo przebywali w Wiedniu, w pobliskiej, ongiś kuracyjnej miejsowości Kaltenleutgeben oraz w salzburskiej miejscowości alpejskiej Zell am See był pochodzący z Kongresówki Henryk Sienkiewicz, (1846-1916). Z jego licznych powieści popularne „Ogniem i mieczem" oraz „Quo vadis?" powstały właśnie na terenie dzisiejszej Austrii. Nawet Cesarz Franciszek Józef odznaczył go wysokim orderem zasługi w dziedzinie sztuk i nauk. Sienkiewicz obracał sie w barwnym wówczas towarzystwie polskim Wiednia, w kawiarni Puchera przy Kohlmarkt i w hotelu Arcyksiecia Karola przy Kärtnerstrasse. Zaczał ponoć pisać powieść o tejże Polonii wiedeńskiej, ale nigdy nie dokonał tego zamiaru.

Kolejną autorką była Maria Konopnicka (1842-1910), zaaganżowana społecznie, popularna autorka z Kongresówki, pochowana we Lwowie, wiele czasu spędzała na terenie dzisiejszej Austrii, Galicji i Czech. W alpejskiej miejsowosci kuracyjnej Bad Ischl, gdzie i cesarz często spedzał lato. Przypomina pobyty pisarki, napis wyryty tam na kamiennej płycie.

Duży rozgłos nadano Międzynarodowemu Zjazdowi Pisarzy, który odbył się we wrześniu 1881 r. w Wiedniu. Zabłysnął na nim Józef Ignacy Kraszewski (1812-87), autor powieści historycznych z dziejów Polski, wśród rożnych kolegów z emigracji, z Galicji i z Królestwa. Chodziło o zademonstrowanie wspólnoty literatury polskiej poprzez granice zaborów i o prawa autorskie w związku z działalnościa twórców z wielu krajów Europy. Kraszewskiemu, który był bardziej z Saksonią związany niż z Au- 
stria, dzisiaj poświęcone jest ciekawe muzeum biograficzne w Dreźnie. Najbardziej ożywione kontakty literackie polsko-austriackie rozwijały sie jednak nieco później, we wczesnych latach 20. tych XIX wieku. Był to różnorodny, jakże fascynujący po dziś dzień okres modernizmu, w którym wspóistniały prądy jakoby sprzeczne, ale tworzące bogatą calość: naturalizm społeczno-krytyczny obok elitarnego symbolizmu, mistyczna wręcz religijność obok szyderczego satanizmu, wybujałe formy obok rzeczowej trzeźwości, energią kipiący witalizm obok dekadenckiego smutku. Wspólnym mianownikiem było wyłamanie się z pętli konwencji, przesądów i tradycji mieszczańskich, szukanie nowych doswiadczeń i ściśle powiązanie sztuki i poezji.

Dla artystów i pisarzy polskich w ramach Monarchii oznaczało to z jednej strony recepcję nowych prądów na terenie Galicji i zarazem wspóludział w twórczości umysłowej stolicy naddunajskiej. Wszak modernizm był ruchem międzynarodowym, mającym co prawda różne narodowe zabarwienia, ale z zalożenia przekraczającym granice etniczne i państwowe. Wywołało to jakby rozdwojenie jaźni u pewnych przedstawicieli Młodej Polski, zwłaszcza u wszechstronnie uzdolnionego Stanisława Wyspiańskiego, którego orientacja neoromantyczna wymagała nowych zrywów patriotycznych w sensie dążenia do odzyskania niepodleglości zjednoczonych ziem polskich. Przesadne powiązanie inteligencji galicyjskiej z kolegami wiedeńskimi i łagodne rządy austriackie jego zdaniem usypiały uczucia narodowe, dążąc do estetycyzmu i kosmopolityzmu. Wystarczy spojrzeć na słynny dramat liryczny "Wesele“ i na niezbyt udany satyryczny wiersz poswięcony Wiedniowi.

Pomimo to Wyspiański jako członek krakowskiej „Sztuki“ czynnie współdziałał z wiedeńską Secesją której stał się także członkiem. Nigdy przedtem i potem koła twórcze Krakowa i Wiednia nie byly sobie tak bliskie jak wtedy. Dwie inne osobistości, jakże różne, warto tu wymieniż, Przybyszewskiego i Rittnera. Widać zresztą wyraźnie i sprzeczność zachowawczych i nowatorskich tendencji wsród polskich kół Wiednia: hr.Karol Lanckoroński zwalczał Secesję jako zwyrodniała, propagująca brzydotę i zmysłowość płciową - Gustaw Klimt, był mu symbolem tego wypaczenia. Z punktu widzenia artystów sprawa wygladała calkiem inaczej.

Stanisław Przybyszewski (1868-1927), poddany pruski, pochodzil z Kujaw. Władał na równi językiem polskim i niemieckim w jego północnym zabarwieniu. Bywał w Wiedniu, ale głównie żył w Berlinie i Monachium. Ten tzw. satanista zyskał dużą popularność w stolicy Rzeszy, ale cieszył się uznaniem i w Wiedniu, gdzie miewał odczyty i utrzymywał stosunki z Hermannem Bahrem i Karolem Krausem. Trzy z jego sztuk zostały wystawione w wiedeńskim teatrze. W czasie Pierwszej Wojny polski 
teatr urządził kilka wieczorów w Wiedniu na jego cześć. W okresie Monarchii zdarzały się zresztą występy w Wiedniu teatrów polskich z Krakowa i Lwowa. Dawniej również istniały i stałe teatry niemieckojęzyczne w obu głównych miastach Galicji, jak i występy gościnne.

Tadeusz Rittner (1873-1921), syn Edwarda, rektora Uniwersytetu Lwowskiego i c.k. ministra oświaty unikał wszelkich skandali w przeciwieństwie do „enfant terrible” Stanisława Przybyszewskiego. Pisał sztuki, powieści, nowele i felietony wielokrotnie w obu językach. Żyjąc w Wiedniu od jedenastego roku życia, należał do typowej rodziny polsko-austriackiej. Obracał się w najlepszych kołach polskich stolicy, u Lubomirskich, Madeyskich, Ziemiałkowskich i Bilińskich. W latach 1914-18, kiedy skutkiem działań wojennych szczególnie wiele Polaków przebywało w stolicy cesarskiej, zajmował się uciekinierami z ramienia Naczelnego Komitetu Narodowego (NKN). Burgtheater, jedna z czołowych scen języka niemieckiego, wystawiła dwie z jego sztuk, „Głupi Jakób“ i „Wilki w nocy“. Często pisywał do „Wiedeńskiego Kuriera Polskiego“ w owych latach wojennych. W swoich pamiętnikach („Moje życie“/"Mein Leben“) ubolewa nieco na pewne rozdwojenie jaźni, jako człowieka należącego zarazem do świata germańskiego i słowiańskiego. Mimo że po $1918 \mathrm{r}$. przybrał obywatelstwo polskie, pozostał w małej Republice Austriackiej i zmarł w Bad Gastein w 1921 r., nie mogąc się skądinąd pogodzić z rozpadem drogiej mu do końca Monarchii Habsburgów.

\section{Gente Iudaei, natione Poloni}

$\mathrm{Na}$ szczególne uznanie jako budowniczych pomostów polsko-austriackich zasłużyło szereg intelektualistów i publicystów pochodzenia żydowskiego, którzy wybrali drogę asymilacji z polskością. Przykładowo należy tu wspomnieć kilkoro z nich. Julian Kłaczko (1825-1906), zdecydowanie antycarski i antypruski konserwatysta katolicki, był doradcą kanclerza Beusta i poplecznikiem niedoszłego sojuszu austriacko-francuskiego w okresie wojny $1870 \mathrm{r}$.

Siegfried Lipiner (1856-1911) z Jarosławia, poeta i dramatopisarz, dyrektor biblioteki wiedeńskiej Rady Państwa i przyjaźnił się z Gustawem Mahlerem. Tłumaczył Mickiewicza i Krasińskiego: zawdzięczamy mu Pana Tadeusza w wersji niemieckiej. Jego wszechstronny umysł cenili sobie Friedrich Nietzsche, i czołowy myśliciel austriackiego katolicyzmu neoromantycznego, Richard Kralik, a zarazem i przywódcy socjalistyczni Victor Adler i Engelbert Pernerstorfer, nie mówiąc o wpływowych polskich osobistościach jak Franciszek Smolka i Karol hr. Lanckoroński. 
Z licznej, uszlachconej i zasłużonej na wielu polach rodziny Blumenstock-Halban Heinrich (Henryk,1865-1926) był doradcą trzech premierów - Alfreda Potockiego, Eduarda Taaffe i Kazimierza Badeniego. Publicysta i konserwatywny Alfred (1865-1926) - profesorem historii prawa uniwersytetów lwowskiego i czerniowieckiego, autorem licznych książek polskich i niemieckich a Josef (1870-1937) znanym ginekologiem. Ze swoją żona, śpiewaczką operową Selmą Kurz (1874-1933) prowadził znany w Wiedniu salon literacki.

Słynny aktor Bogumił Dawison (1818-72) grywał przez pięć lat główne role w wiedeńskim Burgtheater pod dyrekcją Heinricha Laube, nim nie przeszedł do Drezna w 1854 r. Jako jeden z czołowych polskich reżyserów teatralnych zabłysnął w wiedeńskim Burgtheater naszych czasów rodowity lwowianin Erwin Axer w latach 70. XX wieku.Urzekający pięknem języka i głębokością myśli był dramatopisarz i eseista polski Roman Brandstaetter, pobożny katolik i świecki teolog a zarazem wnuk rabina tarnowskiego. Kilka z jego sztuk zostały w ogóle po raz pierwszy wystawione a to właśnie po niemiecku w latach sześćdziesiątych XX wieku przez wiedeński Burgtheater lub na samym zachodzie Austrii w Bregenz przy tamtejszym letnim festiwalu przyciagającym liczna międzynarodowa publiczność nad Jezioro Bodeńskie.

Parlament wiedeński, czyli austriacka Rada Państwa, widział przed 1918 r. wielu zaangażowanych posłów polsko-żydowskich, przeważnie z ramienia konserwatystów lub później socjaldemokratów, typowych "gente Judaei, natione Poloni“, z których rożni udzielali się też piórem. Inni wykształceni Żydzi galicyjscy wybrali drogę germanizacji i wywodząc się z Galicji, wyjeżdżali na stale do Wiednia lub Berlina. Publicyści syjonistyczni, już w przede dniu I wojny światowej, pisali poniekąd i po polsku i po niemiecku.

\section{Muzyka}

Wielki Fryderyk Chopin (1810-49) dwukrotnie, w 1829 r i 1830/31, mieszkał i występował w Wiedniu. W czasie Powstania Listopadowego tęsknił szczególnie do Polski, nie mogąc jednak powstańcom przyjść z pomocą. Wiedeńczycy uznawali jego talent, aczkolwiek nie osiągnął popularności równej Schuberta lub Beethovena. Częściowo tylko trafił do ówczesnego gustu wiedeńskiego swoją urzekającą co prawda, ale zbyt rzewna melancholia, pomimo sympatii, którą darzono powstańców przeciw caratowi.

Obok kilku mniej dzisiaj znanych kompozytorów okresu klasycyzmu znaczni polscy wirtuozi jak Henryk Wieniawski (1835-80), Mieczysław Karłowicz (1876-1909) czy dopiero Ignacy Jan Paderewski (1860-1941) lub 
głośny Karol Szymanowski (1882-1937) mieszkali i studiowali w Wiedniu, światowej metropolii muzyki. Uczyli się po części u wielkiego pedagoga Teodora Leszetyckiego (1835-1915), który od 1878 r. jako „Leschetitzky“ żył i pracował w Wiedniu. W XX wieku gwiazdy polskiej muzyki względnie pochodzący z Polski sławni wykonawcy jak Ignacy Friedmann, Artur Rubinstein i Bronisław Hubermann lub śpiewak Jan Kiepura parokrotnie występowali w wiedeńskich salach.

Za to w odwrotnym kierunku Franz Xaver Mozart (1791-1844), syn słynnego Wolfganga, jako kompozytor, pianista i pedagog muzyczny przez dobrych trzydzieści lat, od 1808 z przerwami aż po 1838 r. żył i pracował w Lwowie. Był nauczycielem muzyki u szlacheckich rodzin, zwłaszcza w pobliskim Podkamieniu u hrabiów Baworowskich i założycielem Lwowskiego Towarzystwa Muzycznego. Miewał i koncerty na terenie ówczesnego Królestwa Polskiego, w Warszawie i Lublinie.

\section{Malarstwo}

Z romantyków zdolny portrecista urodzony na Podolu szlachcic Henryk Rodakowski (1823-94) studiował w Wiedniu po ukończeniu praw i malarstwo u czołowych mistrzów biedermeieru jakim byli Friedrich von Amerling, Josef Danhauser i Franz Eybl. Malował magnatów, ale i chłopów i Żydów. „Posłowie u Sobieskiego“(1861) przypomina wysłanników cesarza Leopolda I. proszących króla Polski o pomoc przeciwko Turkom.

Artur Grottger (1837-67) przedstawiciel romantycznego historyzmu, też pochodził z Podola. Wychowany we Lwowie, namalował w wieku 14 lat Cesarza wjeżdżającego do stolicy Galicji w 1851 r. Obdarzony stypendium cesarskim uczył się w Wiedniu u Karla Blaasa. Pozostawił powstała tamże grafikę i patetyczne cykle z dziejów Polski, zwłaszcza z upamiętniającym ucisk carski, niestrudzone dążenie ku wolności społeczeństwa polskiego i nieszczęście wojen. Utracił stypendium na skutek agitacji politycznej na rzecz powstania styczniowego, niewygodnego dla Monarchii. Władze dokuczały mu na tyle jeszcze w przede dniu wprowadzenia monarchii konstytucyjnej ze rozczarowany opuścił Wiedeń.

Powszechnym zainteresowaniem cieszył się główny przedstawiciel polskiego historyzmu Jan Matejko (1838-1893), który spędził większość życia w Krakowie, ale często bywał w Wiedniu, udekorowany przez cesarza, który go i odwiedził w krakowskim atelier. Jako autor monumentalnych płócien uwiecznił i wspólne dzieje polsko-austriackie jakim były zjazd wiedeński habsbursko-jagielloński w $1515 \mathrm{r}$. i bitwa pod Wiedniem w $1683 \mathrm{r}$.

Z „dynastii“ Kossaków Juliusz Kossak (1824-99), słynny ze swych motywów końskich, namalował wjazd Franciszka Józefa do Krakowa, Jana 
Sobieskiego pod Wiedniem i Maksymiliana Rodakowskiego, generała austriackiego narodowości polskiej, wiodącego atak w bitwie pod Custozzą w 1866 r. Syn jego Wojciech Kossak (1857-1942) uwiecznił w portretach dwóch cesarzy, Franciszka Józefa i Wilhelma II., oraz austriackiego następcę tronu Franciszka Ferdynanda. Henryk Rodakowski (1823-94) portretował i panów galicyjskich. I on studiował w Wiedniu u profesorów Danhausera i Eybla.

Aleksander Kotsis (1836-77) jako zdolny uczeń wielkiego Ferdynanda Georga Waldmüllera oddawał pędzlem życie wiejskie Podkarpacia przypominając silnie austriacką szkołę biedermeiera. Dobrą renomą $\mathrm{w}$ towarzystwie wiedeńskim jak i galicyjskim cieszyli się dalsi portreciści jakim byli obydwaj Ajdukiewicze, stryj Tadeusz (1852-1916) i bratanek Zygmunt (1861-1917), oddając się scenom dworskim i wojskowym. Znany jest motyw Cesarza Austrii przy manewrach pędzla Tadeusza, który objął w 1884 r. warsztat po zmarłym wcześnie Hansie Makarcie, przodującym wówczas mistrzem wiedeńskiego historyzmu. Zygmunt za to sporządził maskę pośmiertna nieszczęsnego arcyksięcia Rudolfa, który jeszcze $\mathrm{w}$ dniu śmierci pozował $\mathrm{w}$ atelier artysty, pracującym nad portretem niedoszłego następcy tronu. Czołowym przedstawicielem malarstwa akademickiego, oblubieńcem dworu i wykwintnego towarzystwa stolicy był profesor Akademii wiedeńskiej Kazimierz Pochwalski (1855-1940) lat 1893-1918. Jego salonowy realizm zachwycał pięknymi motywami dostojnych osobistości ze świata arystokracji, nauki i kultury.

Ostatnim z długiej serii polskich portrecistów działających w Wiedniu, który pracował przez wiele lat uczeń Pochwalskiego Bolesław Jan Czedekowski (1885-1969), równie znany w Paryżu czy w Nowym Jorku. Już wcześniej owocnie rozwijała się współpraca między krakowską Sztuką a wiedeńska Secesja między przedstawicielami Młodej Polski i Hagenbundu. Polscy malarze jak, obok wyżej wymienionych, Julian Falat, Jacek Malczewski, Józef Mehoffer lub Leon Wyczółkowski udzielali się w Secesji. Prace polskich artystów na ogół bywały bardzo przychylnie omawiane przez wiedeńskich krytyków, takimi jak Ludwig Hevessi i Bertha Zuckerkandl-Szeps, prowadząca jeden z głównych salonów literackich Wiednia.

\section{Tematyka polska u autorów austriackich języka niemieckiego}

W literaturze austriackiej XIX wieku tematykę polską względnie galicyjską natrafiamy parokrotnie. Karl Emil Franzos, zasymilowany do niemieckości syn żydowskiej rodziny z Czortkowa w „Pół-Azji“ i innych 
opowiadaniach przetacza życie Żydów galicyjskich w niezbyt przychylnym dla Polaków, zwłaszcza szlachty, społeczno-krytycznym świetle.

Podobno podchodził do rzeczy Leopold v.Sacher-Masoch, syn lwowskiego dyrektora policji za kanclerza Metternicha, pełen współczucia dla nędzy biednych Żydów i chłopów ruskich, krytyczny wobec rewolucyjnych spisków wśród szlachty polskiej z ówczesnej pozycji austriackich władz centralnych. Tu porządek i postęp, to monarchia, dbająca o poddanych, w przeciwieństwie do byłej, egoistycznej i anarchicznej samowoli szlacheckiej. Czytamy o tym w „Polnische Revolutionen“ (Polskie rewolucje), „Der Emissär" (Emisariusz) i w dalszych opowiadaniach. Słynniejsze od samego autora stało się pojęcie masochizmu wywodzące się z jego nazwiska.

Pełne sympatii dla sprawy polskiej są opowiadania Marii v.Ebner-Eschenbach, pisarki pochodzącej z zamożnych kręgów ziemiaństwa morawskiego, opisujące tzw. rabacja galicyjska z 1846 r.: „Der Kreisphysikus“ i „Jakob Szela“. Podobnie wyraża się późniejszy bohater Wiosny Ludów, rozstrzelany w Wiedniu w jesieni 18148 r. Caspar Wenzel Messenhauser, który przedtem służył jako oficer garnizonu galicyjskiego, w swoim opowiadaniu „Polengräber" (Polaków Groby) opisując wydarzenia roku 1846.

Uprzejmie o Polakach wyrażał się również Constantin Freiherr von (baron) Wurzbach, oficer i bibliotekarz, autor wielkiego dzieła biograficznego znaczących osobistości austriackich. Do rzędu literackich „Polenlieder", czyli propolskich pieśni powstałych w krajach niemieckojęzycznych na skutek Powstania Listopadowego 1830/31 przyczynili się znani autorzy austriaccy XIX wieku jak Franz Grillparzer (skądinąd i autor romantycznej opowieści „Der Kastellan von Sendomir“/Kasztelan sandomierski) i Nikolaus Lenau.

W XX wieku górowała epiczna szerokość, głębia swoich powieści i opowiadań oraz subtelnością swego stylu, parokrotnie przedstawiając świat starej Monarchii i Galicji Joseph Roth (1894-1939). W beletrystyce swojej „Radetzkymarsch” (Marsz Radeckiego) „Die Büste des Kaisers” (Popiersie Cesarza) czy „Das falsche Gewicht“ (Fałszywa waga) poruszają tą tematykę w sposób nadzwyczaj sugestywny, pokazując ginąca starą Austrię. Nowo powstałą Polskę i jej bogatą literaturę pokazuje Roth w różnych reportażach i felietonach. Roth przedstawiał Żydów, z których się wywodzil, będąc rodem z Brodów i arystokratów polskich, którzy go fascynowali.

Ekspresjonistyczny dramaturg Franz Theodor Csokor (1885-1969) w sztuce "Jadwiga“ idealizuje pochodzącą z Węgier królową żonę Władysława Jagiełły. W „3. November 1918“ pokazuje rozpad armii austro - węgierskiej przy końcu pierwszej wojny światowej, szlachetnie rysując 
wśród towarzyszy broni innych narodowości Polaka Kamińskiego. Csokor przełożył „Nie-boską komedię“ Zygmunta Krasińskiego i pisał o Mickiewiczu. Po aneksji Austrii przez Niemcy hitlerowskie w 1938 r. wyjechał do Polski, skąd musiał w 1939 r. dalej uciekać do Rumunii i Jugosławii. Kampanię wrześniową opisuje w "Als Zivilist im polnischen Krieg“ (Jako cywil w polskiej wojnie), zawartego później w "Auf fremden Straßen“ (Na obcych drogach). Ten wielki przyjaciel Polski za swoje zasługi otrzymał w 1963 roku order Polonia Restituta.

Elitarno-zachowawczy powieściopisarz o eleganckim stylu i nonszalanckim sposobie bycia, Alexander Lernet-Holenia (1897-1976) dwie książki poświecił tematyce polskiej: „Die Abenteuer eines jungen Herrn in Polen" (1931)/Przygody młodego pana w Polsce/ opisując romantyczną i nieszczęśliwą miłość austriackiego oficera i polskiej ziemianki w latach Pierwszej Wojny Światowej i „Mars im Widder“ (1941), w której opisał kampanię wrześniową 1939 r. w duchu sprzecznym z ideologią nazizmu, tak że dzieło zostało szybko skonfiskowane. W popularyzacji literatury polskiej niemałe zasługi odniosła rodowita łodzianka protestancko-niemieckiego pochodzenia, córka fabrykanta Gerda Leber-Hagenau, pisząc o Mickiewiczu, tłumacząc Romana Brandstaettera, Ludwika Hieronima Morstina, Włodzimierza Odojewskiego, Jana Parandowskiego. Jako wielbicielka Jana Sobieskiego napisała i książkę o tym polskim królu. Wnikliwe sztuki Brandstaettera o tematyce moralno-religijnej jak "Dzień gniewu“ przeważnie miewały premierę w wiedeńskim Burgtheater właśnie w niemieckim przekładzie Pani Leber-Hagenau.

Jako wielostronny historyk, genealog, krytyk literacki i publicysta Otto Forst-Battaglia (1889-1965), dziadek autora tego rozdziału, pisał w tej kolejności po niemiecku, po francusku i po polsku. Szerzył osiągniecia polskiego życia umysłowego, literatury i historiografii, w krajach niemiecko-i francuskojęzycznych $\mathrm{w}$ okresie międzywojennym i powojennym. Poświecił osobne biografie dwóm polskim królom, Janowi Sobieskiemu i Stanisławowi Auguście Poniatowskiemu. Pisząc sporo o sprawach polskich, odbywał regularne wykłady o dziejach i piśmiennictwie polskim na Uniwersytecie Wiedeńskim. Wrocławski germanista Krzysztof Huszcza poświecił mu obszerną biografię. W latach 2009 i 2010 w Wiedniu a potem we Wrocławiu, Stacja PAN oraz Ossolineum urządziły sympozjum na cześć tego wybitnego uczonego. W ostatnim dziesięcioleciu swego życia przyjmował on u siebie licznych polskich intelektualistów, pisarzy i naukowców odwiedzających Wiedeń, takich jak Jan Parandowski, Roman Brandstaetter, Zygmunt Czerny, Stanisław Kot, Stanisław Stomma, Jakub Sawicki i Stanisław Nahlik. Przez kilkadziesiąt lat prowadził rozległa korespondencję z czołowymi przedstawicielami życia umysłowego Polski. 
O rozszerzenie kontaktów elit intelektualnych obu krajów silnie angażował się publicysta katolicki, redaktor naczelny „Die Furche“ i wieloletni rzecznik prasowy Prezydenta Republiki Austrii Kurt Skalnik (1925-97), zapraszając wybitne osobistości takie jak Władysław Bartoszewski i Tadeusz Mazowiecki. Podobne inicjatywy podejmował i wysoce zasłużony Wolfgang Kraus (1924-98), sekretarz generalny Österreichische Gesellschaft für Literatur (Austriackie Towarzystwo Literatury), popierając znanych, nie reżimowych intelektualistów z krajów ówczesnej Wschodniej Europy dzięki krótszym lub dłuższym stypendiom w Austrii.

Rozpowszechnianiem wiedzy o Polsce i przybliżaniem jej Austriakom oddawał się przez dziesiątki lat Theodor Kanitzer, przewodniczący Towarzystwa Austriacko-Polskiego w Wiedniu. Młodszy Martin Pollack, pisarz i publicysta, przywołał do życia modną znów od jakiegoś czasu Galicję. Jest on wielce zasłużonym budowniczym pomostów, jakim był i zmarły już pisarz i przedsiębiorca, pochodzący z Drohobycza Adam Zieliński (1929-2010).

Austriackim pisarzem bezpośrednio pochodzącym z Polski, dwujęzycznym ale głównie publikującym po niemiecku jest mieszkający w Wiedniu i pod Warszawą Radek Knapp. Stanowi on w swojej osobie jakoby współczesną syntezę polsko-austriacką.

Należy w tym miejscu wspomnieć i o slawistach, szerzących wiedzę o Polsce, jakimi byli ongiś przy wszechnicy wiedeńskiej zwłaszcza Günther Wytrzens (1922-91) i Bonifacy Miązek lub ucząca języka polskiego - Zofia Zielińska, a dawno przed nią już Roger Forst-Battaglia (1903-88) oraz o historykach jak Heinrich Felix Schmid (1896-1963) i Walter Leitsch (1926-2009). Szkole tłumaczy języka polskiego założyła w Wiedniu Dorothea Müller-Ott. Szczególnie czynnymi są dzisiaj w tej dziedzinie Liliana Niesielska i Joanna Ziemska. Naukę o kraju i kulturze polskiej (Landes-und Kulturkunde Polens) wykładali na slawistyce Jakub Forst-Battaglia a po nim teatrolog Jerzy Got-Spiegel (1928-2004), autor ciekawych dzieł o historii teatrów austriackich grających w XIX wieku po niemiecku w Krakowie i w Lwowie.

Obecnie Polską zajmują się w Wiedniu profesorowie Christoph Augustynowicz jako historyk a literaturą i kulturą Alois Woldan jako slawista. Sporo jest i lektorów przybywających z Polski.

\section{8. "Mit Austrii w literaturze polskiej”}

Znakomitą i oryginalną pracę pod tym tytułem przedłożył Alois Woldan. Należy ją przeczytać aby uzupełnić skomplikowany obraz tych stosunków i zrozumieć pozorne sprzeczności między rożnymi sposobami 
recepcji tego "mitu“. Są one bowiem typowo środkowoeuropejskim objawem kolidujących ze sobą albo uzupełniających się wzajemnie tożsamości narodowych, etnicznych i kulturowych. Wielojęzyczność, państwo narodowe tak jak i ponadnarodowe moga zależnie od okresu wstecz patrząc wydawać się przydatne albo zwyrodniale, źródłem konfliktów lub właśnie szansa ich przezwyciężenia przez pokojowe wyrównanie sił. Nacjonalizm wychwalający "czystość etniczna“ lub panowanie jednej narodowości nad innymi, widzimy to po doświadczeniach $X X$ wieku, pozornie tylko potrafi zaspokoić potrzeby tego lub innego narodu. Zwycięstwo jednego oznacza porażkę drugiego co doprowadza przeważnie do nowych, jeszcze gorszych konfliktów, wojen i totalitaryzmów. W ten sposób nie dziwi, że z polskiej perspektywy najpóźniej od polowy lat 60. XX wieku spojrzenie na Monarchię Naddunajską wstecz staje się coraz przychylniejsze. Dali temu wyraz autorzy tak różni jak Andrzej Kuśniewicz, Julian Stryjkowski, Andrzej Stojowski, Tadeusz Kudliński lub Ryszard Sadaj. Owszem, dostrzegano tu i znamiona stabilności, praworządności lub pokojowego w miarę uporania się z konfliktami.

W okresie międzywojennym, po odzyskaniu niepodległości przez nowo wskrzeszona, walcząca do 1922 r. o granice i ład wewnętrzny Druga Rzeczpospolita, ogół autorów, o ile w ich twórczości występował jakiś watek galicyjski lub staro austriacki, woleli w czambuł potępiać ten okres wspólnych dziejów, wskazując na zgniły, bałwochwalczy, represyjny i służalczy charakter Cesarstwa i oportunizm „,czarnożółtych krakauerów lub galileuszy“. Galicja, to zły starosta Breinl płacący za zamordowanych przez chłopów w 1846 r. ziemian, to represje okresu Metternicha lub nędza Galicji wykorzystywanej przez „chytrych hofratów“ wiedeńskich, nie postęp, parlamentaryzm i państwo prawa, nie udział Polaków w rządach Monarchii, nie szkoły i swoboda kultury polskiej, nie polski język urzędowania w przeciwieństwie do innych zaborów, lecz ucisk narodowy i szerzenie waśni przez biurokracje austriacka popierająca Ukraińców albo jakiś śmieszny lojalizm pozbawiony zdrowego, czysto narodowo polskiego patriotyzmu. Ideologia czy to legionowa, czy dopiero endecka, mimo że się ze sobą absolutnie nie zgadzały, wspólnie odrzucały austriackie dziedzictwo Galicji i nim gardziły, powracając do pojęcia Małopolski nawet na jej wschodniej części, kiedyś zwanej Rusią Czerwona przed rozbiorami. Niestety Polska międzywojenna nie potrafiła rozwiązać swoich sprzeczności narodowościowych i przekonać różne silne żyjące w niej mniejszości narodowe do lojalności wobec Państwa, co wrogowie Polski mogli łatwo wykorzystać.

W Austrii z kolei, zdezorientowanej, rozdartej wewnętrznie i nie wierzącej w siebie miedzy 1918 a 1938 rokiem, ideologia wszechniemiecka 
dawała się we znaki, zastępując ponadnarodowy monarchizm. Rozczarowanie, nawet rozpacz nad stracona, większą ojczyzną i jej zapleczem gospodarczym była olbrzymia. O Galicji chętnie zapominano, chyba ze myśląc o niej w kontekście odrzucania przybyszy żydowskich $\mathrm{z}$ tych stron. W sposobie obchodów 250. rocznicy odsieczy wiedeńskiej 1683 r., prowadzonych faktycznie $\mathrm{w}$ duchu wielkoniemieckim, mimo że i niby „niemiecko-chrześcijańskim“, odgraniczającym się od hitlerowskiej Rzeszy, zmniejszano celowo rolę Sobieskiego. Państwo polskie w 1938 r. nie zareagowało szczególnie na "Anschluss" Austrii. Beckowska polityka, co prawda w obliczu bierności mocarstw zachodnich, wolała jeszcze niebawem podzielić się z Niemcami i Węgrami kęsem Czechosłowacji.

Prawym przyjacielem biednej a straconej małej Austrii okazał się ówczesny poseł polski w Wiedniu Jan Gawroński, który pozostawił nadzwyczaj wnikliwe wspomnienia z lat trzydziestych. Uratował on chociaż prowizorycznie szereg Żydów polskich zamieszkałych w Wiedniu wożąc ich autem oficjalnym do pobliskiej Bratysławy. Po napadzie Niemiec hitlerowskich na Polskę służyli i Austriacy w szeregach Trzeciej Rzeszy, niektórzy z nich byli i zbrodniarzami wojennymi. Żydzi austriaccy ginęli w obozach na terenie Generalnej Guberni. Byli i antyhitlerowcy, pomagający Polakom, a nawet Żydom skazanym na zagładę, co oznaczało wysokie ryzyko. Przeciwnicy reżimu również trafiali do obozów na terenie Polski okupowanej. Propaganda hitlerowska utwierdzała rzekomą wyższość „rasy germańskiej” nad Słowianami.

W tradycji polskiej się tego Austriakom jako takim nie wypomina. Po 1955 r. Austria była krajem wolnym i prosperującym, jej losy powojenne potoczyły się zgolą inaczej niż losy Polski. Umysłowo odcinano się możliwie od świata komunistycznego. Oba kraje wiec dosyć głęboko oddaliły się od siebie w świadomości. Lecz w dobrej tradycji austriackiej niezabarwionej pangermanizmem sympatie do Polaków wyrosły z dawnych już, ale głębokich wspólnych doświadczeń i z podziwu dla dzielnego i nieugiętego, europejskiego i chrześcijańskiego narodu.

Powoli od lat 80. szerzył się mit Europy Środkowej, do tego należała i stopniowa „rehabilitacja“ Galicji, która i dla pewnych Austriaków nabierała charakter nierealnej, zamierzchłej krainy czarów, często symbolizującej zapadły świat malowniczego getta i harmonijnego współżycia w idealnym „Mitteleuropa“. Dla Polaków Galicja stawała się niby pomostem łączącym ich bezpośrednio ze światem Zachodu i cywilizacji europejskiej. Oczywiście były to i sztuczne konstrukty oderwane od rzeczywistości. Lepiej wszak o takie dobrotliwe legendy niż o wrogie stereotypy szerzące nienawiść. Stać nas teraz z odstępem czasu na spojrzenie bardziej obiektywne. Wreszcie po dziesięcioleciach istnienia Żelaznej Kurtyny 
i prawie ćwierć wieku normalnego współżycia w środkowej, znów na innych warunkach zjednoczonej Europie możemy się nawzajem lepiej poznać bez uprzedzeń i przesadów i nawiązać do najlepszych wspólnych tradycji, zarazem budując nowoczesna przyszłość w globalnym świecie.

\section{Bibliografia wybrana}

Batowski H., Die Polen, [w:] Die Habsburgermonarchie 1848-1918, Band 3. Die Völker des Reiches, Wien 1980, s.522-544.

Brandys B., Franz Theodor Csokor. Identität von Leben und Werk, Łódź 1988.

Buszko J., Galicja 1859-1914. Polski Piemont?, Warszawa 1989.

Chledowski K., Pamiętniki, t. 1: Galicja 1843-1880, Wrocław 1951. t. 2: Wiedeń 1881-1901, Kraków 1957.

Człowiek Śródeuropy. Otto Forst de Battaglia (1889-1965), (red.) K. Huszcza, A. Juzwenko, M. Zybura, Wrocław 2011.

Daszyński I., Pamiętniki, t. 1, Kraków 1925, t. 2, Kraków 1926.

Forst-Battaglia J., Galizien und sein Osten, Land der Begegnungen - Realität und Mythos. Ukrainer, Polen und Juden im alten Österreich, [w:] Österreichisch-ukrainische Begegnungen, Lviv-Charkiv 2013, s. 105-128.

Forst-Battaglia J., Polnisches Wien, Wien-München 1983.

Forst de Battaglia O., Jan Sobieski, König von Polen, Einsiedeln-Zürich 1946.

Forst de Battaglia O., Stanislaw August Poniatowski und der Ausgang des alten Polenstaates, Berlin 1927.

Forst de Battaglia O., Das katholische Schrifttum Polens, Freiburg im Breisgau 1934.

Forst de Battaglia O., Zwischeneuropa. Von der Ostsee bis zur Adria, t. 1: Polen, Tschechoslowakei, Ungarn, Frankfurt 1954.

Gawroński J., Moja misja w Wiedniu 1932-1938, Warszawa 1965.

Grodziski S., Franciszek Józef I, Kraków 1983.

Huszcza K., Polska i Polacy w pracach Ottona Forst de Battaglii, Kraków 2002.

Kuryluk E., Wiedeńska apokalipsa, Kraków 1974.

Mantel F., Wachlarz wspomnień, Paryż 1980.

Orłowski H. (wyd.), Osterreichisch-polnische literarische Nachbarschaft. Materiały z konferencji (Poznań 30.11.-2.12.1977), Poznań 1979.

Polen-Österreich. Aus der Geschichte einer Nachbarschaft, Hrsg. von W. Leitsch und M. Wawrykowa, Wien/Warszawa 1988.

Pollack M., Po Galicji. O chasydach, Hucułach, Polakach $i$ Rusinach. Imaginacyjna podróż po Galicji Wschodniej i Bukowinie, czyli wyprawa w świat, którego nie ma, przeł. A. Kopacki, Wołowiec 2007.

Polska-Austria. Drogi porozumienia, (red.) K. A. Kuczyńskiego, A. Kozłowskiego, B. Miązka, Łódź 1999.

Rosco-Bogdanowicz M., Wspomnienia, Kraków 1959.

Studia Austro-Polonica. Zeszyty Naukowe Uniwersytetu Jagiellońskiego CCCCLXXXII. Prace Historyczne, Zeszyt 57, Warszawa-Kraków 1978. 
Studia Austro-Polonica. Zeszyty Naukowe Uniwersytetu Jagiellońskiego DLXXXII. Prace Historyczne, Zeszyt 68, Warszawa-Kraków 1980.

Taborski R., Wśród wiedeńskich poloników, Warszawa 1974.

Wereszycki H., Pod berłem Habsburgów, Kraków 1975.

Witos W., Moje wspomnienia, t. 1, Warszawa 1988, t. 2, Warszawa 1990.

Woldan A., Mit Austrii w literaturze polskiej, Kraków 2002.

Zybura M. (Hrsg./Wyd.), Ein Erasmus unserer Zeit. Otto Forst de Battaglia- Schriften zur polnischen Literatur, Darmstadt 1992.

\section{Zusammenfassung}

\section{ZWISCHEN WIEN UND GALIZIEN, ÖSTERREICH UND POLEN- EIN KALEIDOSKOP DER KULTURBEZIEHUNGEN VOM 18.BIS INS 20. JAHRHUNDERT}

Polnische Eliten der Geburt und des Geistes spielten nach den Teilungen Polens, durch die Galizien 1772 an Österreich gekommen war, eine nicht zu unterschätzende Rolle im kaiserlichen Wien. Deutschsprachige Österreicher kamen als Beamte und Militärs nach Galizien. Es gab zahllose Ebenen des Austauschs und der Begegnungen über mehrere Generationen hinweg. Nach 1918 trugen galizische Polen ihre Erfahrungen altösterreichischer Rechtsstaatlichkeit in die wiedererweckte Rzeczpospolita. Nach 1945 schnitt der Eiserne Vorhang künstlich Europa in zwei, doch schufen später gerade die Neutralität Österreichs ab 1955 und die, nach 1956, dann wieder nach 1970 relativ gemäßigtere Kulturpolitik im kommunistischen Polen günstige Voraussetzungen für eine Annährung unter aufgeschlossenen Intellektuellen. Dazu trug die Schaffung eines Österreichischen Kulturinstituts in Warschau 1964, eines Fensters zur westlichen Welt und eines Polnischen Instituts in Wien 1974 wesentlich bei. Zur Zeit der Solidarnosc-Bewegung 1980/81, dann während der düsteren Tage des Kriegsrechts in Polen fanden etliche polnische Intellektuelle den Weg nach Österreich. Die österreichische Öffentlichkeit, zumal die Gebildeten, nahmen regen Anteil an den Ereignissen in Polen, dessen ungebrochener Freiheitswille im Streben nach Demokratie und Menschenrechten überwiegend auf große Sympathie stieß. Nach dem Fall des Kommunismus 1989 herrschten nun endlich Bedingungen für einen freien Austausch, der durch fähige Diplomaten, wie den angesehenen Publizisten und nachmaligen Außenminister Wladyslaw Bartoszewski, geschickte Kulturvermittler und engagierte Wissenschafter wesentlich ausgebaut und vertieft werden konnte. Das neuerrichtete Wiener Zentrum der Polnischen Akademie der Wissenschaften bot eine Plattform für zahllose Veranstaltungen auf hohem Niveau.

\section{Salons und Mäzene}

Im 18.und 19.Jahrhundert brillierte die Fürstenfamilie Czartoryski mit ihrem Palais im Wiener Vorort Weinhaus. Der Direktor der Hofbibliothek Józef Maksymilian Graf Ossolinski zur Zeit von Kaiser Franz schuf auch das nach ihm benannte Nationalinstitut in Lemberg, Karl Graf Lanckoronski-Brzezie besaß eine der größten privaten Kunstsammlungen Wiens. Im gesellschaftlichen und politischen Leben der Hauptstadt spielten die Grafen Agenor Goluchowski der Ältere, Alfred Potocki und Kazimierz Badeni als Regierungschefs, Agenor Goluchowski der Jüngere als Außenminister oder Julian Dunajewski und Leon Bilinski als Finanzminister eine wichtige Rolle. Landsmannminister Kazimierz Chledowski und der Hofkämmerer Marian Rosco-Bogdanowicz hinterließen, der eine aus- 
führliche Satiren der Wiener Gesellschaft, der andere bunte Memoiren des Lebens in der Kaiserstadt.

\section{Literaten}

Zahlreiche polnische Schriftsteller lebten und arbeiteten in Wien und in Kurorten des heutigen Österreich oder sie kamen gerne zu Besuch in die Donaumetropole. Denken wir an Henryk Sienkiewicz, den Autor von "Quo vadis“ und der "Trilogie“ aus den polnischen Kriegen des 17.Jahrhunderts, an Maria Konopnicka, an den Meister des Jungen Polen der Jahrundertwende Stanislaw Wyspianski oder an den deutsch-polnischen Bühnenautor und Sohn eines weiteren galizischen Landsmannministers Tadeusz Rittner. Während des Ersten Weltkriegs war Wien ein beliebter Treffpunkt für polnische Literaten, Publizisten und Schauspieler. Es gab polnische Zeitschriften und Theateraufführungen.

\section{Gente Iudaei, natione Poloni}

Eine bedeutsame Rolle als geistige Bindeglieder zwischen Wien und Galizien, der polnischen und der deutschösterreichischen Kultur spielten jüdische Persönlichkeiten wie der Parlamentsbibliothekar, Autor und Übersetzer Siegfried Lipiner, der Schauspieler Bogumil Dawison, der Publizist und Außenamtsberater Julian Klaczko oder drei Mitglieder der Familie Halban-Blumenstock die sich als als Ministersekretäre und Professoren verdient machten, um nur einige zu nennen. Nach 1945 stach der betont katholisch-jüdische, polnische Autor Roman Brandstaetter hervor, dessen beste Dramen gerade in deutscher Fassung am Wiener Burgtheater oder bei den Bregenzer Festspielen erstaufgeführt wurden.

\section{Musik}

Frederic Chopin war wohl der berühmteste zeitweise in Wien tätige polnische Komponist. Nach ihm wirkten im 20.Jahrhundert bekannte Persönlichkeiten wie Henryk Wieniawski oder Karol Szymanowski oder der Musikpädagoge Teodor Leszetycki (Theodor Leschetytzky) in der österreichischen Hauptstadt.

\section{Maler}

Romantiker wie Henryk Rodakowski, Artur Grottger oder Aleksander Kotsis, der bedeutende Historienmaler Jan Matejko, die Porträtisten und Pferdemaler Juliusz und Wojciech Kossak, der Realist Kazimierz Pochwalski oder die Vertreter des Jungen Polen und Anhänger der Sezession und des Hagenbunds Julian Falat, Jacek Malczewski, Jozef Mehoffer und Leon Wyczolkowski wirkten in Wien.

\section{Polnische Thematik bei deutschösterreichischen Autoren}

$\mathrm{Ob}$ kritisch, ausgewogen oder voller Sympathie und Anteilnahme, immer jedoch sehr engagiert widmeten sich so unterschiedliche Autoren wie Karl Emil Franzos, Leopold von Sacher-Masoch, Marie von Ebner-Eschenbach, Caspar Wenzel Messenhauser, Constantin Frh.von Wurzbach, Franz Grillparzer, Joseph Roth, Franz Theodor Csokor, Alexander von Lernet-Holenia oder neuerdings Adam Zielinski und Martin Pollack polnischen und galizischen Themen. Die Übersetzerin und Autorin Gerda Leber-Hagenau trug viel zur Popularisierung polnischen Schrifttums in Östrreich bei. Als nimmermüder geistiger Brückenbauer, Historiker, Genealoge, Literaturkritiker und Publizist, bleibt Professor Otto Forst-Battaglia allen, die ihn und seine Werke gekannt haben unvergeßlich. Der katholische Journalist und Buchautor Kurt Skalnik erwarb bleibende Verdienste bei der Festigung 
des Verständnisses für Polen in Österreich indem er bedeutende Persönlichkeiten wie Wladyslaw Bartoszewski und Tadeussz Mazowiecki nach Wien einlud. In ähnlicher Weise betätigte sich Wolfgang Kraus als bewährter Gastgeber polnischer Literaten.

"Der österreichische Mythos in der polnischen Literatur"

Unter diesem Titel legte der österreichische Slawist Alois Woldan eine profunde und originelle Arbeit vor, die am Beispiel der etwas verklärt-sublimierten Darstellung von Galizien und Österreich in der polnischen Literatur der Zeit nach dem Zweiten Weltkrieg, im Gegensatz zum mehrheitlich negativen Bild, das in der polnischen Zwischenkriegszeit von der Habsburgermonarchie herrschte, eine Beschreibung typisch mitteleuropäischer, nationaler und kultureller Mythen versucht. Jakub Forst-Battaglia vergleicht polnische und österreichische Denkschemata und schlägt einen ausgewogenen Zugang vor, der zu einem konstruktiven und freundschaftlichen Zusammenleben im vereingten, freien Europa von heute führen soll. 